\title{
PENGARUH CAR, NPF,BOPO DAN LDR TERHADAP ROA BANK UMUM SYARIAH YANG TERDAFTAR DI BANK INDONESIA
}

\author{
HUTOMO MANDALA PUTRA \\ Mahasiswa Magister Manajemen Pascasarjana Universitas Islam Malang \\ Email :Tommyred@gmail.com
}

\begin{abstract}
Abstrak
Tujuan penelitian ini adalah : untuk menguji Bagaimana gambaran secara menyeluruh tetang rasio keuangan periode tahun 2012 sampai 2016 Bagaimana pengaruh permodalan kualitas aset, rentabilitas, likuiditas terhadap kinerja bank umum syariah.

Sampel yang digunakan dalam penelitian ini adalah perusahaan perbankan bank umum syariah yang terdaftar di bank indonesia serta menyajikan laporan keuangan periode 2012-2016. Hasil penelitian ini menunjukan bahwa Dalam penelitian ini rasio-rasio keuangan CAR, dan BOPO, untuk bank umum syariah berpengaruh terhadap ROA signifikan, sedangakan NPF dan LDR berpengaruh terhadap ROA namun tidak signifikan pada profitabilitas bank syariah devisa di indonesia dan menggunakan metode camel minus manajemen dengan 4 variabel.
\end{abstract}

Kata kunci : ROA, CAR, NPF, ROA, dan LDR

Abstract
The purpose of this study is: to test How the overall picture of the ratio of the financial period of 2012 to 2016 How the effect of capital asset quality, profitability, liquidity to the performance of sharia commercial banks.

The sample used in this research is banking company of sharia bank which is registered in bank indonesia as well as present financial report for period 20122016. The results of this study show that in this study, the financial ratios of CAR, and BOPO, for syariah commercial banks have significant effect on ROA, while NPF and LDR have an effect on ROA but not significant on the profitability of sharia foreign exchange bank in Indonesia and using camel minus management method with 4 variables.

Keywords: ROA, CAR, NPF, ROA, and LDR

\section{PENDAHULUAN}

Kinerja bank merupakan hal yang penting karena merupakan cerminan dari kemampuan bank dalam mengelola aspek permodalan dan asetnya dalam mendapatkan laba. Implikasi dari fungsi bank sebagai intermediary maka likuiditas bank diukur berdasarkan kredit yang disalurkan kepada masyarakat di banding dana yang diberikan oleh pihak ketiga. Fenomena yang terjadi adalah dimana keadaan perekonomian Indonesia di sector perbankan mengalami keadaan yang pasang surut. Ketidakstabilan disebabkan karena adanya ancamang lobalisasi dan pasar bebas di kancah ekonomi internasional. (Viethzal Rivai,2007,699)

Perbankan Syariah adalah segala sesuatu yang menyangkut tentang Bank Syariah dan Unit Usaha Syariah, mencakup kelembagaan, kegiatan usaha, serta cara dan proses dalam melaksanakan kegiatan usahanya. ( UU Nomor 21 Tahun 2008 Tentang Perbankan Syariah). Faktanya konteks pengelolaan perekonomian makro, meluasnya 
penggunaan berbagai produk dan instrument keuangan syariah akan dapat merekatkan hubungan antara sector keuangan dengan sector riil serta menciptakan harmonisasi di antara kedua sector tersebut. Semakin meluasnya penggunaan produk dan instrument syariah disamping akan mendukung kegiatan keuangan dan bisnis masyarakat juga akan mengurangi transaksi-transaksi yang bersifat spekulatif, sehingga mendukung stabilitas system keuangan secara keseluruhan, yang pada gilirannya akan memberikan kontribusi yang signifikan terhadap pencapaian kestabilan harga jangka menengah-panjang. Dengan telah diberlakukannya Undang-Undang No.21 Tahun 2008 tentang Perbankan Syariah yang terbit tanggal 16 Juli 2008, maka pengembangan industri perbankan syariah nasional semakin memiliki landasan hukum yang memadai dan akan mendorong pertumbuhannya secara lebih cepat lagi. Dengan progres perkembangannya yang impresif, yang mencapai rata-rata pertumbuhan asset lebih dari $65 \%$ pertahun dalam lima tahun terakhir, maka diharapkan peran industry perbankan syariah dalam mendukung perekonomian nasional akan semakin signifikan.

Bank Syariah adalah Bank yang menjalankan kegiatan usahanya berdasarkan Prinsip Syariah dan menurut jenisnya terdiri atas Bank Umum Syariah dan Bank Pembiayaan Rakyat Syariah. Prinsip Syariah adalah prinsip hukum Islam dalam kegiatan perbankan berdasarkan fatwa yang dikeluar-kan oleh lembaga yang memiliki kewenangan dalam penetapan fatwa di bidang syariah (Booklet Perbankan Indonesia, 2011).

\section{KAJIAN TEORI}

Rasio-rasio yang akan digunakan dalam penelitian ini adalah rasio CAMEL yakni : CAR(Capital Adequacy Ratio), Earning asset quality (EAQ), ROA( Return On Assets), dan LDR (Loan To Deposit Ratio). Rasio-rasio tersebut sudah dapat menggambarkan kinerja keuangan secara keseluruhan (Kasmir,2014:48).

Sesuai dengan rasio CAMEL maka digunakan perhitungan rasio sebagai berikut:

1. Capital adequacy ratio (CAR).

Rasio ini sebagai salah satu indikator kemampuan bank dalam menutup penurunan aktiva sebagai akibat kerugian yang diderita bank. (veithzal rivai,2013:473). Rasio ini dapat dirumuskan sebagai berikut:

$\mathrm{CAR}=$

$$
\frac{\text { modal bank }}{\text { aktiva tertimbang menurut risiko (ATMR) }} \times 100 \%
$$

2. Non Performing Financing (NPF).

Rasio ini adalah kredit bermasalah yang terdiri dari kredit yang berklasifikasi kurang lancar, diragukan dan macet. NPL diperuntukkan bagi bank umum, sedangkan NPF untuk bank syariah. (www.bi.go.id) Rasio ini dapat dirumuskan sebagai berikut:

$$
\mathrm{NPF}=
$$

$\frac{\text { Kredit yang diberikan dengan kolektabilitas }}{\text { total kredit yang diberikan }} \times 100 \%$

(2)

Non Performing Financing (NPF) adalah kredit-kredit yang tidak memiliki performance yang baik dan diklasifikasikan sebagai kurang lancar, 
diragukan dan macet. Tugas Bank Indonesia (BI) antara lain adalah mempertahankan dan memelihara sistem perbankan yang sehat dan dapat dipercaya dengan tujuan menjaga perekonomian. Untuk itu BI selaku Bank sentral dan pengawas perbankan di Indonesia memberikan ketentuan ukuran penilaian tingkat kesehatan Bank. Salah satu ketentuan BI mengenai NPF adalah Bank-Bank harus memiliki NPF kurang dari 5\%.

3. Beban Operasional Pendapatan Operasional (BOPO)

Rasio ini adalah perbandingan antara biaya operasional dengan pendapatan operasional dalam mengukur tingkat efisiensi dan kemampuan bankdalam melakukan kegiatan operasinya (veithzal rivai,2013:482).

Dalam hal ini perlu diketahui bahwa usaha utama bank adalah menghimpun dana dari masyarakat dan selanjutnya menyalurkan kembali kepada masyarakat dalam bentuk kredit, sehingga beban bunga dan hasil bunga merupakan porsi terbesar dalam suatu bank.Rasio ini dapat dirumuskan sebagai berikut:



Dimana :

A. Biaya operasional adalah semua biaya yang berhubungan langsung dengan kegiatan usaha bank yang pada umumnya terdiri dari : biaya bunga, biaya valas, biaya tenaga kerja, penyusutan, dan biaya lainnya.

B. Pendapatan operasional adalah semua pendapatan yang merupakan hasil langsung dari kegiatan usaha bank yang benar-benar telah diterima, terdiri dari hasil bunga,provisi dan komisi, pendapatan valas, dan pendapatan lain-lainnya.

4. Loan To Deposit Ratio (LDR). Loan to deposit Ratio Rasio ini adalah rasio yang mengukur perbandingan jumlah kredit yang diberikan bank dengan dana yang diterimah oleh bank, yang menggambarkan kemampuan bank dalam membayar kembali penarikan dana oleh deposan dengan mengandalkan kredit yang diberikan sebagai sumber likuiditasnya. (Veithzal Rivai,2013:484) Dengan rumusan sebagai berikut :

$$
\mathrm{LDR}=\frac{\text { jumlah kredit yang diberikan }}{\text { total dana pihak ketiga }} \times 100 \%
$$

Ketentuan tentang LDR adalah sebagai berikut:

bank indonesia menetapkan rasio LDR sebesar $110 \%$, atau bila melebihi diberi nilai kredit nol yang artinya likuiditas bank tersebut dinilai tidak sehat. Dan untuk rasio LDR di bawah 110\% diberi nilai kredit 100 yang artinya likuiditas bank tersebut dinilai sehat.(Veithzal Rivai,2013:484).

Kerangka pemikiran yang akan digunakan didalam penelitian ini mengenai pengaruh permodalan, kualitas aset, manajemen, rentabilitas dan likuiditas terhadap kinerja bank. Kerangka pemikiran hubungan antar variabel adalah sebagai berikut. 
Gambar 2.1

Model Kerangka Pemikiran

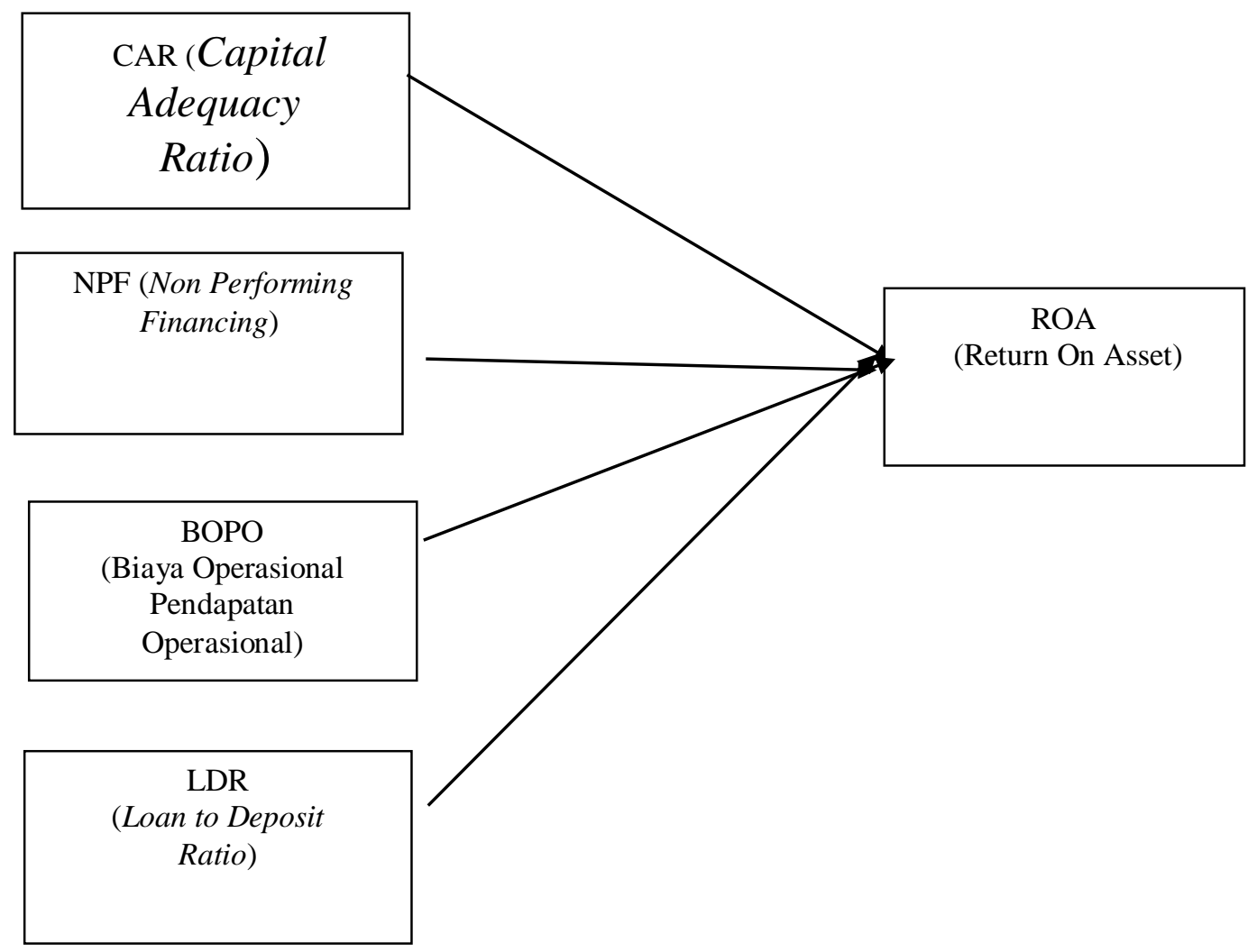

Berdasarkan kerangka berfikir di atas maka di hipotesiskan bahwa Capital Adequacy Ratio (CAR), Non Performing Financing (NPF), BOPO, Net Income Margin (NIM), Loan Deposit Ratio (LDR) berpengaruh secara simultan terhadap Return On Asset (ROA).

\section{METODE PENELITIAN}

Data yang digunakan dalam penelitian ini adalah data sekunder berupa data kinerja keuangan perusahaan yang meliputi data Capital Adequacy Ratio (CAR), Non Performing Financing (NPF), BOPO, Loan to Deposit Ratio (LDR).Data yang digunakan dalam penelitian ini diperoleh dari Statistik Bank Umum Syariah Indonesia tahun 2012-2016 dan data laporan keuangan bank syariah Devisa yang ada di Indonesia pada periode penelitian yaitu 2012-2016 diperoleh di www.bi.go.id.

Populasi yang digunakan dalam penelitian ini adalah Perbankan umum Syariah Devisa selama periode 2012-2016 yang diperoleh di www.bi.go.id.

Metode sampling yang akan digunakan didalam penelitian ini adalahmetode purposive sampling, yaitu teknik penentuan sampel dengan memilih sumber data berdasarkan kriteria-kriteria serta berdasarkan pertimbangan-pertimbangan tertentu. Sampel yang digunakan dalam penelitian ini harus memenuhi kriteria sebagai berikut: 
a. Perusahaan perbankan syariah yang terdaftar di Bank Indonesia selama periode 2012-2016.

b. Data laporan keuangan tahunan untuk periode 2012-2016 tersedia di dalam website www.bi.go.id

c. Bank yang diteliti masih beroperasi selama periode 2012-2016.

\section{HASIL ANALISIS DATA}

Pada analisis data ini akan dilakukan analisis secara deskriptif sesuai dengan perhitungan yang dilakukan pada, Bank Mega Syariah, Dan Bank BNI Syariah, Bank Mandiri Syariah, Bank Mega Syariah, dan Bank Muamalat selama periode tahun 2012 sampai dengan tahun 2016. CAR $\left(\mathrm{X}_{1}\right)$ terhadap ROA $(\mathrm{Y})$.

Nilai koefisien CAR untuk variabel $X 1$ sebesar 0,064 . Hal ini mengandung arti bahwa setiap kenaikan CAR satu satuan maka ROA (Y) akan meningkat sebesar 0,064 dengan asumsi bahwa variabel bebas yang lain dari model regresi adalah tetap.

Nilai koefisien NPF $X_{2}$ sebesar 0,508 dan bertanda negatif, ini menunjukkan bahwa NPF mempunyai hubungan yang berlawanan arah dengan ROA. Hal ini mengandung arti bahwa setiap kenaikan NPF maka ROA (Y) akan turun sebesar 0,508 dengan asumsi bahwa variabel bebas yang lain dari model regresi adalah tetap.

Nilai koefisien BOPO $X_{3}$ sebesar $-0,164$ dan bertanda negatif, ini menunjukkan bahwa BOPO mempunyai hubungan yang berlawanan arah dengan ROA. Hal ini mengandung arti bahwa setiap kenaikan BOPO satu satuan maka ROA (Y) akan turun sebesar -0,164dengan asumsi bahwa variabel bebas yang lain dari model regresi adalah tetap.

Nilai koefisien LDR $X_{4}$ sebesar $-0,011$ dan bertanda positif, ini menunjukkan bahwa LDR mempunyai hubungan yang searah ROA. Hal ini mengandung arti bahwa setiap kenaikann LDR satu satuan maka ROA(Y) akan naik sebesar-0,011dengan asumsi bahwa variabel bebas yang lain dari model regresi adalah tetap.

\section{PEMBAHASAN}

\section{Pengaruh Permodalan CAR $\left(\mathrm{X}_{1}\right)$ terhadap ROA $(\mathrm{Y})$.}

Dari hasil perhitungan secara partial variabel CAR berpengaruh signifikan positif terhadap ROA yang di tunjukkan Nilai koefisien CAR untuk variabel $X 1$ sebesar 0,064 . Hal ini mengandung arti bahwa setiap kenaikan CAR satu satuan maka ROA (Y) akan meningkat sebesar 0,064. Alasannya signifikannya CAR terhadap ROA dikarenakan sebagian besar nilai CAR pada Bank Umum Syariah di Indonesia, pada periode penelitian cenderung konstan. Tanda positif pada koefisien variabel CAR menunjukkan sebagian besar data pada periode penelitian ketika nilai CAR mengalami kenaikan. Sebagai misal nilai CAR pada Bank Mega Syariah tahun 2015 mengalami kenaikan pada 2016 sedangkan ROA pada tahun 2015-2016 mengalami kenaikan.

Dari analisis dapat di simpulkanbahwa CAR berpenaruh positif terhadap ROA. Hal ini sesuai dengan hipotesis yang menyebutkan CAR 
berpengaruh positif terhadap ROA. Hasil penelitian ini menguatkan penelitian yang dilakukan oleh Ayuningrum (2011).

\section{Pengaruh Kualitas Aset NPF ( $\left.\mathrm{X}_{2}\right)$ terhadap ROA (Y).}

Dari hasil perhitungan secara partial variabel NPF berpengaruh positif terhadap ROA secara signifikan. Pengaruh signifikan ditunjukkan Nilai koefisien NPF $X_{2}$ sebesar 0,508 dan bertanda positif, ini menunjukkan bahwa NPF mempunyai hubungan yang berlawanan arah dengan ROA. Hal ini mengandung arti bahwa setiap kenaikan NPF maka ROA (Y) akan turun sebesar 0,508 dengan asumsi bahwa variabel bebas yang lain dari model regresi adalah tetap. Nilai positif pada koefisien regresi variabel NPF menunjukkan sebagian besar data pada periode penelitian ketika nilai NPF mengalami penurunan. Sebagai misal, nilai NPF pada Bank BNI Syariah yang mengalami penurunan pada tahun 2012-2013.

Dari hasil analisis dapat disimpulkan NPF berpengaruh positif terhadap ROA, hal ini tidak sesuai dengan hipotesis yang menyebutkan bahwa NPL perpengaruh negative terhadap ROA.

Hasil penelitian ini konsisten dengan hasil penelitian yang dilakukan oleh Rusdiana (2012) dan tidak konsisten dengan penelitian terdahulu yang dilakukan oleh Ayuningrum (2011). Dimana hasil penelitiannya menunjukkan bahwa NPF berpengaruh negatif terhadap ROA.

\section{Pengaruh Rentabilitas BOPO $\left(\mathrm{X}_{3}\right)$ terhadap ROA $(\mathrm{Y})$.}

Dari hasil perhitungan secara partial variabel BOPO berpengaruh negatif terhadap ROA secara signifikan. Pengaruh signifikan ditunjukkan Nilai koefisien BOPO $X_{3}$ sebesar $-0,164$ dan bertanda negatif, ini menunjukkan bahwa BOPO mempunyai hubungan yang berlawanan arah dengan ROA. Hal ini mengandung arti bahwa setiap kenaikan BOPO satu satuan maka ROA (Y) akan turun sebesar -0,164 dengan asumsi bahwa variabel bebas yang lain dari model regresi adalah tetap. Nilai negatif pada koefisien regresi variabel BOPO menunjukkan sebagian besar data pada periode penelitian ketika nilai BOPO mengalami kenaikan. Sebagai misal, nilai BOPO pada Bank BNI Syariah yang mengalami penurunan pada rasio rata-rata tahun 2012-2016.

Dari hasil analisis dapat disimpulkan BOPO berpengaruh negatif terhadap ROA, hal ini tidak sesuai dengan hipotesis yang menyebutkan bahwa BOPO perpengaruh negative terhadap ROA.

Hasil penelitian ini konsisten dengan hasil penelitian yang dilakukan oleh Mahardian (2018) dan tidak konsisten dengan penelitian terdahulu yang dilakukan oleh Nusantara (2019). Dimana hasil penelitiannya menunjukkan bahwa BOPO berpengaruh positif terhadap ROA.

\section{Pengaruh Likuiditas LDR $\left(\mathrm{X}_{4}\right)$ terhadap ROA $(\mathrm{Y})$}

Dari hasil perhitungan secara partial menunjukan bahwa variabel LDR berpengaruh signifikan Negatif terhadap ROA. Hal tersebut ditunjukkan Nilai koefisien LDR $\mathrm{X}_{4}$ sebesar -0,011 dan bertanda positif, ini menunjukkan bahwa LDR mempunyai hubungan yang searah ROA tetapi 
tidak signifikan. Hal ini mengandung arti bahwa setiap kenaikan LDR satu satuan maka $\mathrm{ROA}(\mathrm{Y})$ akan naik sebesar -0,011dengan asumsi bahwa variabel bebas yang lain dari model regresi adalah tetap. Pengaruh LDR yang signifikan negatif bahwa semakin rendah LDR suatu bank maka semakin kecil kredit yang disalurkan, yang akan menurunnya kinerja suatu bank. Nilai negatif pada koefisien variabel LDR menunjukkan sebagian besar data pada periode penelitian ketika nilai LDR mengalami penurunan, Seperti yang terlihat pada Lampiran 4, sebagai misal nilai LDR Bank mandiri syariah mengalami penurunan rata-rata rasio pada tahun 2012-2016

Dari hasil analisis dapat disimpulkan bahwa LDR berpengaruh negatif terhadap ROA. Hal tersebut tidak sesuai dengan hipotesis yang menyebutkan LDR berpengaruh positif terhadap ROA.

Hasil penelitian ini konsisten dengan hasil penelitian yang dilakukan oleh Rusdiana (2012) dan tidak konsisten dengan penelitian terdahulu yang dilakukan Nusantara (2009). Dimana hasil penelitiannya menunjukkan bahwa LDR berpengaruh positif terhadap perubahan laba secara signifikan

\section{SIMPULAN DAN SARAN}

Capital Adequacy Ratio (CAR) berpengaruh positif dan signifikan terhadapReturn On Asset (ROA). Hal ini menunjukkan bahwa semakin besar Capital Adequacy Ratio (CAR) maka Return On Asset (ROA) yang diperoleh bank akan semakin besar karena semakin besar Capital AdequacyRatio (CAR) maka semakin tinggi kemampuan permodalan bank dalammenjaga kemungkinan timbulnya risiko kerugian kegiatan usahanyasehingga kinerja bank juga meningkat.

Non Performing Financing (NPF) berpengaruh negatif dan tidak signifikan terhadap Return On Asset (ROA). Pada periode penelitian tingkat Non Performing Financing (NPF) perusahaan perbankan masih tergolong rendah, yaitu dibawah $5 \%$. Sehingga perlu adanya kehatian-hatian pihak perbankan dalam menjalankan fungsinya. Risiko berupa kesulitan pengembalian kredit oleh debitur dengan jumlah yang cukup besar dapat mempengaruhi kinerja perbankan. Terdapatnya kredit bermasalah tersebut menyebabkan kredit yang disalurkan banyak yang tidak memberikan hasil.

BOPO berpengaruh negatif dan signifikan terhadap Return On Asset (ROA). Sehingga semakin besar BOPO, maka akan semakin kecil ataumenurun kinerja keuangan perbankan. Begitu juga sebaliknya, jika BOPOsemakin kecil, maka dapat disimpulkan bahwa kinerja keuangan suatuperusahaan (perbankan) semakin meningkat atau membaik.

Loan to Deposit Ratio (LDR) berpengaruh positif dan signifikan terhadap Return On Asset (ROA). Jika rasio Loan to Deposit Ratio (LDR) bank berada pada standar yang ditetapkan oleh Bank Indonesia, maka laba yang diperoleh oleh bank tersebut akan meningkat (dengan asumsi bank tersebut mampu menyalurkan kreditnya dengan efektif). Dengan meningkatnya laba, maka Return On Asset (ROA) juga akan meningkat, karena laba merupakan komponen yang membentuk Return On Asset (ROA). 


\section{DAFTAR RUJUKAN}

Bank Indonesia. 2004. Tata Cara Penilaian Tingkat Kesehatan Bank. Peraturan Bank Indonesia No. 6/10/PBI tanggal 12 April . (online), (http://www.bi.go.id)

Booklet Perbankan Indonesia. 2011. Jakarta : Bank Indonesia

Ghozali, Imam. 2011. Aplikasi Analisis Multivariate dengan Program IBM SPSS 19. Edisi 5. Badan Penerbit Universitas Diponegoro, Semarang. Kasmir. 2011. Dasar-dasar Perbankan. Jakarta: PT Raja Grafindo Persada. Kasmir. 2012. Analisis Laporan Keuangan. Rajawali Pers, Jakarta.

Kasmir. (2014). Bank dan Lembaga Keuangan Lainnya. Edisi Revisi, Cetakan keempatbelas, PT. RajaGrafindo Persada, Jakarta.

Kasmir.(2014). Dasar-Dasar Perbankan. Edisi Revisi, Cetakan ke duabelas, PT. RajaGrafindo Persada, Jakarta.

Mahardian, Pandu. 2008. "Analisis Pengaruh Rasio CAR, BOPO, NPL, NIM Dan LDR Terhadap Kinerja Keuangan Perbankan (Studi Kasus Perusahaan Perbankan yang Tercatat di BEJ Periode Juni 2002-Juni 2007)". Tesis Program Pascasarjana Studi Magister Manajemen Universitas Diponegoro.

Nusantara, A.B. 2009. "Analisis Pengaruh NPL, CAR, LDR, Dan BOPO Terhadap Profitabilitas Bank (Perbandingan Bank Umum Go Publik dan Bank Umum Non Go Publik di Indonesia Periode Tahun 20052007)". Tesis Program Pascasarjana Studi Magister Manajemen Universitas Diponegoro.

Rusdiana, Nana. 2012. "Analisis Pengaruh CAR, LDR, NIM, NPL, BOPO, Dan DPK Terhadap Kinerja Keuangan Perbankan (Studi Kasus pada Bank Umum yang Terdaftar pada Bursa Efek Indonesia Periode 2008-2011)". Skripsi Program Sarjana Jurusan Manajemen Fakultas Ekonomika dan Bisnis Universitas Diponegoro.

Veithzal Rivai. (2007). Bank and Financial Institute Management. Jakarta: PT. Raja Grafindo Persada.

Veithzal Rivai. (2013). Manajemen Sumber Daya Manusia untuk Perusahaan : Dari Teori ke Praktik Edisi Kedua. Jakarta: PT. Rajawali Pers

Nusantara, A.B. 2009. "Analisis Pengaruh NPL, CAR, LDR, Dan BOPO Terhadap Profitabilitas Bank (Perbandingan Bank Umum Go Publik dan Bank Umum Non Go Publik di Indonesia Periode Tahun 20052007)". Tesis Program Pascasarjana Studi Magister Manajemen Universitas Diponegoro. 